Research Article

\title{
Exploring the functionality of English in China: A tale of two cities
}

\author{
Zhichang XU ${ }^{1}$ and Danya ZHANG ${ }^{2}$ \\ ${ }^{1}$ School of Languages, Literatures, Cultures and Linguistics, Monash University \\ Melbourne, Australia \\ ${ }^{2}$ School of Foreign Languages and Literature, Yunnan Normal University \\ Kunming, China
}

\begin{abstract}
The world of English has been witnessing shifts and turns over the last half century, and a major one is a paradigm shift from a monolithic English to pluricentric Englishes. The term "Englishes" symbolizes the "functional and formal variation in the language, and its international acculturation" (Kachru B. \& Smith 1985: 210), and it is primarily concerned with the "intelligibility of form, comprehensibility of meaning, and interpretability of sense" (Proshina 2014: 4). As far as China is concerned, there are estimated 350-500 million learners and users of English, and the functions of English have expanded since the "reform and open door" policies of the 1970s (Kirkpatrick \& Xu 2002). In this paper, we explore the expanding functionality of English in China, taking the major shifts and turns surrounding world Englishes as a backdrop, that is, the shift from codifying linguistic features of English varieties to focusing on users' translanguaging practices in multilingual contexts, as well as the functional turn, the multilingual turn, and the dynamic interactive turn (Sridhar \& Sridhar 2018). In particular, we adopt a qualitative approach to researching Chinese English as a translanguaging practice among Chinese English bilingual professionals in order to unpack the expanding functions of English in two major Chinese cities, Beijing and Kunming. Drawing upon semi-structured interviews of Chinese-English bilingual professionals from the two cities, we present a "tale of two cities" in relation to the expanding functionality of English in China.
\end{abstract}

Keywords: Chinese English, functionality of English, paradigm shift, functional turn, world Englishes

\section{For citation:}

$\mathrm{Xu}$, Zhichang \& Danya Zhang. 2020. Exploring the functionality of English in China: A tale of two cities. Russian Journal of Linguistics 24 (3). 589-611. DOI: 10.22363/2687-0088-202024-3-589-611 
Научная статья

\title{
Исследование функциональности английского языка в Китае: история двух городов
}

\author{
Ч. СЮЙ, ${ }^{1}$ Д. ЧЖАН ${ }^{2}$ \\ ${ }^{1}$ Университет имени Монаша \\ Мельбурн, Австралия \\ 2 Юньнаньский педагогический университет \\ Куньмин, Китай
}

\begin{abstract}
Аннотация
За последние полвека мир английского языка претерпевает сдвиги и повороты, и одним из главных сдвигов стало изменение парадигмы от монолитического английского языка к плюрицентрической концепции вариантов английского языка. Термин «варианты английского языка» (“Englishes”) означает «функциональную и формальную вариативность в языке и его международную аккультурацию» (Kachru B. \& Smith 1985: 210) и связан прежде всего с «понятностью формы, пониманием значения и интерпретацией смысла» (Proshina 2014: 4). Что касается Китая, в нем насчитывается 350-500 миллионов пользователей и изучающих английский язык, и функции английского языка расширились со времени начала осуществления политики «реформы и открытых дверей» в 1970-х годах (Kirkpatrick \& Xu 2002). Цель данной статьи - исследование расширения функциональных возможностей английского языка в Китае с учетом основных изменений, проявляемых в вариантах английского языка в мире, например, переход от кодификации языковых черт вариантов английского языка к фокусированию внимания на пользователях и их транслингвальных практиках в мультилингвальных контекстах, а также функциональный поворот, многоязычный поворот и динамичный интерактивный поворот (Sridhar \& Sridhar 2018). В частности, мы используем квалитативный подход к исследованию китайского варианта английского языка как средства транслингвальной практики билингвальных профессионалов, говорящих на китайском английском. Наша задача - показать расширение функций английского языка в двух крупных городах Китая - Пекине и Куньмине. Опираясь на полуструктурированные интервью, взятые у китайских специалистов, говорящих на английском языке, мы представляем «историю двух городов» в связи с расширением функциональности английского языка в Китае.
\end{abstract}

Ключевые слова: китайский вариант английского языка, функциональность английского языка, смена парадигмы, функциональный поворот, варианты английского языка в мире

\section{Для цитирования:}

$\mathrm{Xu}$ Z., Zhang D. Exploring the functionality of English in China: A tale of two cities. Russian Journal of Linguistics. 2020. Vol. 24. № 3. P. 589-611. DOI: 10.22363/2687-0088-2020-24-3589-611

\section{Introduction}

The world of English has witnessed a major paradigm shift over the last half century, from a monolithic English to pluricentric Englishes. A paradigm is a concept that refers to shared beliefs, assumptions and rules, and it is "a set of recurrent and quasi-standard illustrations of various theories in their conceptual, observational, and instrumental application" (Kuhn 1996: 43). The new paradigm in world Englishes reflects variations in lexis, syntax, discourse, and pragmatics of English varieties in different contexts. According to B. Kachru and Nelson (1996: 
76-77), "the concept of a monolithic English as an exponent of culture and communication in all English-using countries has been a convenient working fiction that is now becoming harder and harder to maintain. What we have now in reality is English languages and English literatures." The plural forms in "English languages and English literatures" indicate the diversity of English varieties around the world and the "multiplex nature of English" (Seargeant 2010: 97). B. Kachru and Smith (1985: 210) have pointed out that the term Englishes symbolizes the "functional and formal variation in the language, and its international acculturation." Such functional and formal variation and international acculturation of English in a global context give rise to the pluralism of English, which in turn results in rising issues of the "intelligibility of form, comprehensibility of meaning, and interpretability of sense" (Proshina 2014: 4) among speakers of world Englishes. Proshina (2014: 1) also points out that one of the salient features of the World Englishes paradigm is the "domineering of a dynamic functionality over a static prescriptive approach." To understand the pluralism and the domineering dynamic functionality of English, "it is therefore vital to see its spread, uses, and users in sociolinguistic contexts" (Kachru B. \& Nelson 1996: 77).

Alongside the major paradigm shift, there have been associated shifts and turns surrounding world Englishes, e.g., the shift of research focus from identifying and codifying features of English varieties to understanding the users and their translanguaging practices in multilingual contexts, and the shift from using English in the real world to an increasingly trans-mediated use of English in the virtual space via social media. In terms of "turns," the world of English has in the past few decades witnessed a functional turn (B. Kachru 1992), a multilingual turn (May 2014), and a dynamic interactive turn (Sridhar \& Sridhar 2018). And more recently, newer turns seem to have emerged, such as a translanguaging turn and a transmedia turn, which we shall propose in this paper in relation to the expanding functionality of world Englishes.

In China there are an estimated 350-500 million learners and users of English with wide ranges of proficiency and competence, and the functions of English in China have expanded since the "reform and open door" policies beginning in the 1970s (Kirkpatrick \& Xu 2002). These Chinese learners and users of English have become increasingly aware of their own use of English in relation to the functions in their local and global contexts. In this paper, we explore the expanding functionality of English in China, taking the major shifts and turns surrounding world Englishes as a backdrop. We adopt a qualitative approach to researching Chinese-English bilingual professionals in order to unpack the expanding functions of English in two major Chinese cities, Beijing and Kunming. Drawing upon semistructured interviews of Chinese-English bilingual professionals from the two cities, we present a "tale of two cities" in relation to the expanding functionality of English in China through addressing the following research questions: 1) What are the functions of English used by Chinese-English bilingual professionals? 2) How are the expanding functions of English mapped onto the linguistic and cultural contexts of China, particularly in Beijing and Kunming? 


\section{Literature review}

The major paradigm shift from English to Englishes implies a number of aspects. For example, English has become a pluricentric and multicultural language, with variations in lexis, syntax, discourse, pragmatics, and cultural conceptualizations across different varieties of English. There has also been a shift in multilingual speakers' perceptions of the role of their first language and culture in relation to English from the "baggage" of negativity as an interlanguage to a "badge" of multilingual identity. In addition, one of the fundamental shifts underpinning the goals of English language teaching (ELT) worldwide is from manufacturing native or near-native speakers of English to developing "effective and strategic translanguaging users of English in multilingual communication contexts" (Xu 2017: 703-704).

Alongside the major paradigm shift in World Englishes, as far as the Outer and Expanding Circle varieties of English are concerned, we have also observed a number of concurrent shifts, e.g., there has been a noticeable shift in research focus from identifying and codifying features of English varieties to the users and their translanguaging practices in multilingual contexts. Seargeant and Tagg (2011: 498) have proposed a "post-varieties" approach to world Englishes studies, which is defined as "an analysis apparatus that is sensitive to the dynamic communicative practices which use English-related forms and connotations as one part of a wider semiotic repertoire." They suggest that "in actual practice, people often mix English with other languages in an ad hoc manner, adding English-related words and phrases while nominally speaking other languages in a way which reflects transnational cultural flows." Canagarajah (2017: 4) has also observed that "in the place of territorialized, bounded, and static ways of talking about language and social practices, we are now adopting constructs that index their mobile, hybrid, and constructed nature."

Apart from the above-mentioned shifts, there have also been functional, multilingual and dynamic interactive turns surrounding the research and practice of world Englishes. We normally speak of a "turn" when there is a "conceptual leap" that moves right across disciplines "as a new means of knowledge and a methodologically reflected analytical category" (Bachmann-Medick 2009: 4). More recently, newer turns have emerged, such as a translanguaging turn and a transmedia turn. In terms of the functional turn, when B. Kachru (1983: 235) investigated the "Indianization of English," he proposed a functional approach to English varieties in "un-English" sociocultural contexts, arguing that "language must be considered an integral part of the meaning system in which it functions, and relates to the contexts in which it is used." B. Kachru (1992: 58) has proposed four functions of English in relation to South Asian English varieties, namely "the instrumental, the regulative, the interpersonal, and the imaginative/innovative":

The instrumental function is performed by English as a medium of learning at various stages in the educational system of the country. The regulative function entails use of English in those contexts in which language is used to 
regulate conduct; for example, the legal system and administration. The interpersonal function is performed in two senses: first, as a link language between speakers of various (often mutually unintelligible) languages and dialects in linguistically and culturally pluralistic societies; and second, by providing a code which symbolizes modernization and elitism. The imaginative/innovative function refers to the use of English in various literary genres. (B. Kachru 1992: 58)

B. Kachru (1992) draws upon these functions from researchers such as Bernstein (1966) and Halliday (1973), who had explored functions of language in a broader sense, e.g., the restricted and elaborated codes of a language serve "functions of a particular form of social relationship, or more generally, of qualities of social structures" (Bernstein 1966: 255). Halliday (1973: 36) proposes that language structures reflect the social uses of the language by the language users, and he argues that adult language can be explained in terms of "macro-functions," including the ideational, the interpersonal, and the textual. Apart from the macrofunctions, Halliday (1973) has also developed a list of functions of language in relation to the personal and social needs of the users, including the instrumental, the regulatory, the interactional, the personal, the heuristic, the imaginative, and the representational/informative.

The "functional turn" in World Englishes is characterised by "the alleviation from the obsession with the target language milieu as prototype acquisition environment" (Sridhar and Sridhar 2018: 130), and it is also characterized by a "pragmatic redefinition of the acquisitional target in terms of intelligibility and communicability and interpretability" of multi-competent English users rather than an "arbitrary, native-like correctness" (Sridhar and Sridhar 2018: 130-131). Alongside the "functional turn" in World Englishes, there is also a "multilingual turn" indexed by rising applied linguistic and sociolinguistic concepts focusing on language users' practice in multilingual contexts, e.g., metrolingualism (Pennycook 2010) and functional bilingualism (Baker 2011). Clyne (2003: 47-48) argues that "bilinguals are not double monolinguals" because they employ resources of their languages so that each language has certain functions, and various combinations of the languages serve to make social and communicative meanings. The multilingual turn implies that multilingual speakers employ language resources in their existing multilingual repertoires legitimately as they engage in their "fluid and overlapping language uses, and related linguistic and sociocultural competencies, of multilingual communities" (May 2014: 7).

From a World Englishes perspective, multilingual English users, by definition, "have more options of codes, strategies, and nuances since they control more than one linguistic system" (Kachru Y. \& Nelson 2006: 19). The multilingual turn is characterized by the perception of multilingual speakers of English as "developing a verbal repertoire - where the two (or more) languages interact with and influence one another, sometimes complementing, sometimes overlapping, to create a composite multilingual competence," and the realization that "the several languages 
(often more than two) in the community's and individual's verbal repertoire together cover the range of functions" (Sridhar and Sridhar 2018: 131).

In addition, there is more recently a "dynamic interactive turn" raised by Sridhar and Sridhar (2018: 132-133), which is based on multilingual speakers' linguistic repertoire models that the World Englishes paradigm has recognised since its inception. The linguistic repertoire model serves to challenge our traditional views of language and grammar. "Multilingual people's grammars are best thought of in terms of 'verbal repertoires'; they use a formally and functionally determined range of languages as part of their competence for linguistic interaction" (Kachru Y. $\&$ Nelson 2006: 20). The current "dynamic interactive turn" moves away from bilingualism as "double monolingualism" or multilingualism as "parallel monolingualisms" (Sridhar and Sridhar 2018: 131), and it recognizes that "the languages of a multilingual not only complement one another in discrete domains, but also overlap one another within many domains" (Sridhar \& Sridhar 2018: 132). The "dynamic interactive turn" views common language practices of multilinguals such as borrowing, transfer, convergence, code-switching, code-mixing, stylistic stratification, and bilingual creativity as "value-added features" and "natural outcrops of the ecology of multilingualism" (Sridhar and Sridhar 2018: 132). In light of the latest developments in applied linguistics and technology-mediated communication, we extend the "dynamic interactive turn" to consider our current translanguaging and transmedia interactions in terms of a translanguaging turn and a transmedia turn surrounding world Englishes.

In terms of a translanguaging turn for World Englishes, we understand translanguaging as a repertoire-based communicative practice among bilinguals and multilinguals. Translanguaging practice is not only dynamic and interactive, but also transformative in nature, because "it creates a social space for the multilingual language user by bringing together different dimensions of their personal history, experience and environment" (Li 2011: 1223). According to Li (2018: 23), "translanguaging underscores multilinguals' creativity - their abilities to push and break boundaries between named languages and between language varieties, and to flout norms of behavior including linguistic behavior, and criticality - the ability to use evidence to question, problematize, and articulate views." A translanguaging turn sets a demand for speakers of world Englishes to develop new competence, and therefore, we propose "translanguaging competence" of world Englishes speakers as a competence that involves "dynamic, embodied and mediated linguistic and cultural repertoires of multilingual users when they make sense of their worlds through languaging as an act and process of sense- and meaning-making across cultures" (Hlavac \& Xu 2020: 20). In relation to the current use of English by world Englishes speakers, we also propose a transmedia turn as an integral part of the "dynamic interactive turn" to account for the many ways in which speakers of world Englishes interact with one another to make and negotiate meaning associated with English across different media, including traditional spoken and print media as well as Internet-based social media. Such a transmedia 
turn may serve to acknowledge a world in which we communicate through various modalities in our objective and virtual realities.

As far as the use of English in China is concerned, $\mathrm{Xu}$ (2010: 1) describes Chinese English as a "developing variety of English, which is subject to ongoing codification and normalization processes." He perceives Chinese English in terms of a "variety" based largely on the two major varieties of English, British and American, characterized by the transfer of Chinese linguistic and cultural norms, and used primarily by Chinese for intra- and international communication. However, in more recent years, in light of the shift of focus from codifying features of varieties to exploring the multilingual practice of the "post-variety" speakers of world Englishes, we propose that Chinese English can be understood from a more functional perspective as a translanguaging practice involving Chinese cultural underpinnings through which English is reshaped and adapted to suit the needs of Chinese English speakers.

Ma and Xu (2017: 191-194) have reviewed the use of English in China in relation to the four major functions outlined by B. Kachru (1992). They observe that the interpersonal function is the most salient among the four functions for a number of reasons, including the increasing interaction between foreign residents living in China and their Chinese counterparts, the unprecedented craze for English among Chinese, Chinese professionals seeking high-end employment and promotion, the rising young urban Chinese professionals who have received quality English education, as well as online social media communication.

The instrumental function of English in China is most visibly observed in the use of English as a medium of instruction (EMI) in the educational system. "Internationalization of education in China entails global exchange - inbound and outbound - of Chinese and foreign teaching staff and students; this is clearly premised on a sound bilingual education system" (Ma and Xu 2017: 192-193). In addition, Fang (2018: 36) observes that "the implementation of EMI is a constantly growing and even inevitable trend as universities view EMI as an important means to internationalize and to attract more international students."

In the imaginative/innovative use of English, Chinese creative writers have been writing in English for over a century, from Lin Yutang in the 1920s and 1930s to Eileen Chang in the 1940s, and more recently, June Chang and Ha Jin. In addition, the imaginative/innovative function of English has been extended to tertiary education, in English creative writing programs and workshops in universities (Dai \& Zheng 2019, Sui 2015).

One of the less salient functions of English in China is the regulative use of English to regulate conduct in terms of administration and law. It may be true that "the regulative function of English is far behind the other three functions, but noticeable changes have been taking place" in China, e.g., "as early as 2008, the Olympic Court in Beijing adopted simultaneous interpretation in English and other foreign languages to cater for the needs of foreign visitors; most of its staff (police and judges) could communicate in English fluently" (Ma \& Xu 2017: 194). 
Although English is increasingly being used in China, serving limited but expanding functions, "there is little research into where exactly English is being used, i.e., who is using Chinese English, with whom and for what purposes?" (Kirkpatrick 2017: 276). Therefore, Kirkpatrick (2017: 278) calls for further research "to investigate the breadth and depth of Chinese English use across China," and he suggests that "the most important question for Chinese English researchers to investigate in the future is the extent to which Chinese English is, in addition to fulfilling an instrumental function of practical use or yong, is also providing Chinese English speakers with some $t i$ or essence as an integral part of their developing identity as multilinguals." (Kirkpatrick 2017: 278). The ti-yong dichotomy consititutes a key pair of terms in Chinese philosophy, with $t i$ representing essense and substance, and yong representing function, application and utility. Chinese people believe that Chinese learning is for $t i$ or essence, and Western learning, including learning English, is for yong or function.

\section{Methodology}

We adopt an analytical framework that is closely related to the major shifts and turns surrounding World Englishes. In particular, we adopt a qualitative approach to data collection and analysis, drawing upon semi-structured interviews of Chinese-English bilingual professionals from Beijing and Kunming so that we explore the expanding functionality of English in China. Our major semi-structured interview questions include:

1) Which areas do you work in?

2) How often and in what circumstances do you use English at work?

3) What functions does English serve for your work?

4) How often and in what circumstances do you use English outside your work?

5) What does English mean to you?

Our participants are ten Chinese-English bilingual professionals based in Beijing and Kunming. The five from Beijing, coded as B1 through B5, are from public relations of corporate businesses, legal industry, state media, education, and medicine. The five from Kunming, coded as K1 through K5, are from medicine, private education, tertiary education and creative writing, the customs office, and information technology.

The semi-structured interviews were largely conducted in Chinese via social media. There were considerable instances of Chinese and English code-mixing and code-switching during the interviews. While transcribing the interview data, both authors of this article translated them from Chinese into English and doublechecked each other's translations. While analysing the data, we incorporate the shifts and turns surrounding World Englishes and our review of Chinese English into the findings and discussions. We conclude the paper by summarising the expanding functionality of the use of English in China. 


\section{A tale of two cities: the use of English in Beijing and Kunming}

We choose Beijing and Kunming to explore the expanding functionality of English in China, primarily because of the geographical locations of the cities and their capital status at the national and provincial levels. In addition, the two authors have lived substantially in the two cities respectively. Beijing (北京) is located in the north of China, and its name literally means "north capital." It is an expanding modern city with an imperial past. Kunming (昆明) is one of the largest cities in Southwest China, known as "the city of eternal Spring." It is the capital city of Yunnan Province with $6 \%$ of its population being ethnic minorities. Historically Kunming was the gateway to the Silk Road facilitating trade with Tibet, Sichuan, Myanmar, India and beyond. Positioned near the border with Myanmar, Laos and Vietnam, Kunming is a Chinese city facing the major member countries of the Association of Southeast Asian Nations (ASEAN).

In the sections below, we analyse the semi-structured interview data of the ten participants, i.e., B1-B5 as the tale of Beijing, and K1-K5 as the tale of Kunming.

\section{B1: "English brings us closer to true realities"}

$\mathrm{B} 1$ is a female participant in her late 40s; she is a public relations (PR) manager for corporate businesses. She majored in English for her Bachelor's degree in the late 1980s. After graduation, she worked for a state-owned company in Beijing, and within two years, she applied to work for a Japanese company in Beijing as a PR manager. After 18 years of working for that company, she moved to a Chinese private enterprise for a similar position as a PR manager.

For B1, English functions as a "working language" first and foremost. The working language status of English, in the context of Beijing, implies its instrumental and interpersonal functions (B. Kachru 1992: 58). Here below is how she elaborated on the "working language" function:

Without knowing English, people wouldn't qualify to work for the Japanese company. So, all the overseas branches use English as their working language. I had worked in the company for 18 years, and over $90 \%$ of the communication was in English, with the headquarters, the bosses and the heads of various departments.

English also functions for B1 as social and cultural capital for getting involved with friends and clubs in Beijing, across China and beyond. This function is associated with the role of English that indexes "internationalism, modernization, innovation, prestige, creativity, and entertainment" (Proshina \& Ustinova 2012: 30). B1 stated:

Beijing is relatively international. The circles that we communicate with, e.g., people from the world economic forum, and organisations such as foreign embassies, and the "wives of ambassadors." There are many international organizations that are interested in China. For example, Page Society is a very 
high-end membership club. They would think that without the heads of communication from Chinese companies, they are not complete.

English apparently serves multiple functions for B1. When asked what English means to her, she responded:

I think English is like a window. When I read English books and write my own prose articles, for example, I feel that I can access fresh perspectives and create ideas. If I didn't know English then I wouldn't be able to access them. English means more opportunities and possibilities. Through English I get to know the realities and developments in foreign countries more directly. So English helps provide a fuller perspective, and English brings us closer to true realities.

\section{B2: "English has gone beyond a tool, pragmatically speaking"}

B2 is a female corporate lawyer in her early 40s working in a law firm specialising in commercial law. Prior to working in Beijing, she did her Bachelor's degree in social sciences in Beijing, and her Master's degree in law in Hong Kong. She had previously worked in law firms in Australia and Hong Kong.

B2 makes full use of her Chinese English bilingual competence for her work, as she works with both Chinese and foreign colleagues and clients. She mentioned that her language choice for work "depends on the clients," and that it is "totally a flexible arrangement." She explained:

I think whether we use English at work depends on the clients. If we have foreign clients, we'd have documents in English. And the foreign clients are not necessarily from English speaking countries, e.g., Japan and Italy. For Chinese clients, it all depends. If the case deals with foreign business, it's likely that we use English.... There are also cases that involve both China and foreign countries, and although we may represent one party, we would prepare bilingual files. So, this is totally a flexible arrangement.

The above excerpt implies that employees in the legal industry involving foreign colleagues and clients need to develop their bilingual and "translanguaging competence" (Hlavac \& Xu 2020: 20). B2's response also shows that there is a "dynamic interactive turn" (Sridhar \& Sridhar 2018: 132-133) taking place as a common practice, which implies that there is a multilingual turn and a translanguaging turn arising, e.g., in B2's words, "you have to keep changing channels ... for practical reasons." She elaborated on her point:

It's more efficient to communicate if we code-mix Chinese with English. ... However, when I code-mix and realise that the other party hesitates a bit, and that he or she may not understand what I mean, I'd shift back to Chinese or explain it again in Chinese. It's like you have to keep changing channels. We have many foreign clients, so we have such a tradition that even for internal emails, we use English, for practical reasons. 
B2's excerpt below shows that English also serves a gate-keeper function for employment in the context of the legal industry in Beijing, and that English offers added value or advantage for people who are in the industry.

And for seeking employments, take our profession for example, if your English is good, it's an absolute advantage. In fact, not all lawyers need English for their work, only a minority of them have to use English, but for recruiting junior employees, it's always expected that their English should be good. So, if your English is good, you'll be far much of an advantage at your interviews.

Outside B2's work, English also serves her in various functions, particularly among the emerging Chinese "middle-class population" for social interactions and accessing information for leisure activities. According to Y. Kachru and Nelson (2006: 88) English may serve as a "high variety" in a diglossic society. B2 elaborated the various functions by saying:

For social interactions, because we have some friends who are foreigners, for example, the parents of my son's classmates, we'd use English. My son's tennis coach is a Japanese, so all the social interactions associated with my son can be in English. For myself, I watch English news, and I watch it daily. And also I'd search for information, such as information about where we'd travel to, I'd browse 'tripadvisor', and that's in English. And also the middleclass population in China is expanding, and their needs, including entertainment, or their life circles, would cross national boundaries.

To B2, English has been a game-changer in the sense that English "has gone beyond a tool," as she identifies herself as part of the bilingual Chinese English middle-class population with a "passport" or broader access to information and resources, and English brings her "closer to the world" as a "global citizen." She said:

I feel like previously English was a tool, or more of a tool, but now I feel it's a part of culture, because English has gone beyond a tool, pragmatically speaking. You'll feel that you can access a lot of information via English so that you may change how you see things, or your perspectives. ... I think if you have been using this language, you'd feel that you're much closer to the world. ... Or you'd feel that you're more like a 'global citizen'. Of course this might sound a bit exaggerating, but you'd feel that English is a passport.

\section{B3: "All sorts of media are full of English, including all kinds of network media"}

B3 is a male journalist working in one of the top state television stations in Beijing. He was interviewed in his workplace in July 2018. He is in his early fifties, and he has been employed by the television station since 1988, with a number of years working as a foreign correspondent in Thailand. His department at the central station features news and feature programs in English for foreign and domestic audiences. 
Having learned and used English in the Chinese context, B3 has witnessed the changing perceptions and functions of English among Chinese people. He recalled:

At the time when I learned English in the 1970s, English was regarded as a profession, now perhaps it's very different. It is more like learning English plus another profession. Learning English, I think it could broaden one's mind, and get to know the outside world.

In addition, B3 has witnessed the changing linguistic and media landscapes of China from the 1970s onwards, from English as a "profession," to the transmedia turn, where there are "all kinds of network media, e.g., self-media," which contribute to the commonness and popularity of English in China. He recalled:

When I started learning English, there were fewer people learning English. I remember that many of my friends ended up being translators, because China was in an urgent need of translation and interpreting professionals. That was 1970s. But later, it was totally different. Now, it's like all sorts of media are full of English, including all kinds of network media, e.g., self-media, all kinds of magazines and newspapers, very widespread, and there are many English programs and foreign language schools, so it means that China is more and more internationalised, and that China is more open, and the environment is more beneficial for the use of English. English has become not just popular but more common now in China.

To B3, English is not only his working language, but a necessary means through which Chinese people share their culture and enhance their cultural confidence. He elaborated on this point:

We often stay in touch with foreigners, and there's a lot to talk about, about our astronomy and geography, customs and conventions, history and culture. We have 5000 years of history, so our history, our experiences and lessons, good or bad, our developments since the reform and open-door policies, our successes, or even our failures, all of these can be the source of our cultural confidence.

\section{B4: "English is more like a part of my self-identity, internalized, with feelings and emotions"}

B4 is a female lecturer in one of the most prestigious universities in Beijing. She is in her mid-30s, and she obtained her Barchelor's and Master's degrees in English language and literature in two universities in Beijing. She teaches English to non-English major students at the university.

To B4, English functions in all aspects of her work, as she works in the English department of the Foreign Languages School of the university. Fang (2018: 36) observes that in the Chinese education domain, particularly in tertiary education, "the implementation of English medium instruction (EMI) is a constantly growing and even inevitable trend." The excerpt below is how B4 described her work: 
In my daily work, I would use English for teaching and communicating with foreign teachers. For teaching, since I teach English, I'd use English most of the time as a medium of instruction, or at least I try to use English throughout my teaching. As I said, I also communicate with foreign teachers in English, for example, writing emails, making phone calls, or chatting via WeChat. I think English has been an integral part of my work, and it goes hand in hand with my Chinese as my working language.

B4's bilingual competence has also been utilized to its full capacity, as she would act as a translator or interpreter on occasion in her workplace, for example, liaising between the Chinese administrative staff and her foreign colleagues. She explained:

I'd sometimes act as a translator or interpreter for our foreign teachers and administrative staff members of the department. They are not formal situations, for example, when the department organize some retreat or Spring outing, I'd interpret for them. You know, being a staff member in the English department, you are always regarded as a translator or interpreter by the school administrative departments.

English has become an indispensable part of B4's life; she said that terms such as "tool" or "profession" were no longer sufficient to describe how she felt about the language. The excerpt below is how B4 elaborated on this point:

English to me has become a part of my life, and it's an indispensable part. Most of the times, I'd do code-switching between Chinese and English, and I find it pretty natural, even subconscious. I wouldn't say English is a tool or a profession, as such terms are a bit too rough, aren't they? Although English can be a tool and a profession and all of those things, I'd say English is more like a part of my self-identity, internalized, with feelings and emotions pretty much involved.

\section{B5: "I can see the world, expand my vision, and facilitate my professional development through this powerful language"}

B5 is a male physician in a Beijing hospital. He is in his late forties. He graduated from the school of medicine of a university in Shanghai.

B5 considers English as a powerful facilitating tool for his work, for example, in expanding his vision and knowledge, and in his practicing evidence-based medicine. According to Y. Kachru and Nelson (2006: 169), English in the Expanding Circle context is "increasingly being used intra-nationally in certain domains such as medical and engineering professions." B5 described the roles of English for his work:

English plays the role of a powerful facilitating tool for my work, e.g., expanding my vision and knowledge in the medical field, practicing evidencebased medicine, publishing papers, and accessing new knowledge and methods in the relevant fields of medicine. To me, English means that I can 
see the world, expand my vision, and facilitate my professional development through this powerful language.

It is evident that English has an expanding functionality, particularly for research and academic purposes, for medical professionals, even though their day-to-day medical practice may not often involve foreign patients. B5 continued by saying that:

In my everyday life, I'd also use English, e.g., learning and exchanging information, watching English videos, foreign movies, and news. And I think the use of English in Beijing is slightly different from other cities, and it's more widespread and more common. English is surely and increasingly used in Beijing, e.g., when I make ward rounds, attend conferences, search for academic literature, see foreign patients, meet foreign medical experts and visit foreign countries. Normally, there aren't many foreign patients seeking medical examinations or treatments in our hospital. Those who come to see us would normally have their own interpreters, but we'd also use English to interact with them.

\section{K1: "I use English to teach medical students"}

$\mathrm{K} 1$ is a female doctor in her early thirties. She graduated from a medical university and then obtained her Master's degree through an on-the-job Master's program. She is currently a doctor in a hospital affiliated with a medical university in Kunming.

While practicing medicine, $\mathrm{K} 1$ also teaches medical students using English as a medium of instruction, and her use of English in teaching the international students is an indication that there is an expanding instrumental function of English in China. She explained the function of English for her work:

I use English to teach medical students. I have some international students from Burma, Thailand, and India. They are medical students. Our hospital is affiliated with the medical university, so some doctors are required to undertake some relevant teaching work.

K1's work includes teaching international students, which has a close relationship with the implementation of EMI in Chinese universities. In K1's case, because of the cooperative relationship between the medical university and the hospital that K1 works for, the instrumental function of English ranges across two domains, education and medical practice.

\section{K2: "I also teach my students mathematics, physics, chemistry, and biology in English"}

$\mathrm{K} 2$ is a male English teacher in a well-known English training school; he is in his late twenties. He obtained his Bachelor's degree in finance. Although K2 did not major in English for his undergraduate studies, he was offered a job in the English training school because of his excellent performance in an English publicspeaking contest. He described his work as follows: 
My work is to teach in English, which includes teaching test preparation courses. Let me calculate the percentage that I use English. I think it really depends on what kind of class I'm teaching. If I'm teaching, like the speaking class, it is definitely over $50 \%$, that's the minimum. As for the intermediate level, it's definitely over $90 \%$, but for the beginners' level, I think it's $50 \%$. I have to speak one English sentence and then a Chinese one to translate it. I also teach my students mathematics, physics, chemistry, and biology in English.

K2's teaching in English indicates that the instrumental function of EMI has shifted from formal education to the private educational services in China. "English is consumed by individuals as well as institutions and organizations" ( $\mathrm{Xu} \mathrm{2009:}$ 124) in English language training schools and centers across China, and English is regarded as a commodity with an exchange value. K2's interview shows that English language training and test preparation courses are in high demand in China, leading to the rapid growth of private English language education services.

\section{K3: "My English poetry writing is my self-expression"}

$\mathrm{K} 3$ is a male university lecturer in Kunming. With both BA and MA degrees in English, K3 has been teaching English for work, and writing poems in English in his spare time since his undergraduate studies. He explained why he wrote poems in English:

I write poems, either in Chinese or in English, just by feeling. I subconsciously think that Chinese poetry is more rhetorical and implicit, which allows people to enjoy the poetic feeling through the beautiful Chinese characters. Comparatively, English poetry is more direct and emphasizes the meaning. I would use English to write the poems which can express explicit feelings.

K3 is conscious of his language choice for his poetry writing. B. Kachru (1985: 20) defines bilinguals' creativity as “those creative linguistic processes which are the result of competence in two or more languages" and asserts that it entails "the use of verbal strategies in which subtle linguistic adjustments are made for psychological, sociological and attitudinal reasons". K3 appreciates both the poetic expression in Chinese and the directness of English, so he takes advantage of the latter to express his multiple Chinese identities in his poem I Am not Me to the World. K3 said that expressing these identities in his first language Chinese might sound overly simple for conveying the poetic "feeling," therefore he chose English to create a straightforward and somewhat philosophical "feeling." K3 explained that his English poetry writing is his "self-expression." He continued by saying:

My English poetry writing is my self-expression. I wrote poetry for myself before I became a father. After becoming a father, maybe subconsciously I think my daughter would be the reader of my poems. Many years later when I pass away, as long as my poetry is alive, my daughter can at least feel that her father was once a living person, not just a few pictures or memories. But now I have changed my mind. If possible, I will publish a collection of English 
poetry. The readers are the ones who like to read poetry, especially my students.

K3's English poetry serves different functions for himself and his readers. From his personal perspective, English poetry is for self-expression. "It can be argued that functional variations in nativized varieties of English, particularly in literary writing, are part and parcel of self-expression, identity construction and transcultural creativity that mark the worldliness of English in an ever-expanding world Englishes literature" (Xu 2020: 88). To K3, English serves as a medium for a bonding experience between family members and an extended readership including those who love English, such as his students.

\section{K4: "We can make efforts in learning English to make Kunming, Yunnan, and China get connected to the international arena"}

$\mathrm{K} 4$ is a male customs officer at Kunming International Airport. He majored in information management and information systems for his Bachelor's degree. After graduation, K4 took the National Civil Service Examination and then was recruited as a customs officer. This is evidenced in $\mathrm{K} 4$ regarding his routine work at the airport:

The international travelers in Kunming are mainly from South and Southeast Asian countries. We might need to communicate with them in English when they have some questions, or they need to declare to us, or we identify people to check and examine. My working area is the international exit/entry where all the signs are in Chinese and English. We also broadcast some regulatory videos, such as the videos about customs laws and regulations in bilingual Chinese and English.

Part of K4's job is communicating with non-Chinese in English regarding relevant regulations. This shows that English serves a regulative function, which is "to regulate conduct, for example, the legal system and administration" (B. Kachru 1992: 58). The use of English in K4's working context is to convey the relevant information about the border security laws and regulations in China to the overseas travelers, so that they can follow the instructions accordingly. K4 emphasized that:

Our country is becoming international. Kunming International Airport is the Bridgehead transportation hub facing Southeast Asia. I think it is good to see Chinese and English here. My colleagues and I try to learn the language knowledge as much as possible in our spare time. We can make efforts in learning English to make Kunming, Yunnan, and China get connected to the international arena.

As shown in the excerpt above, K4 and his colleagues associate their efforts in learning English with the internationalization of Kunming and Yunnan province as well as the image of China in the "international arena." It is worth noting that the Chinese government initiated the Bridgehead Strategy for Yunnan Province in 2009, which stresses the importance of the geographic location of Yunnan, i.e., 
strengthening the cooperation of Yunnan Province, of which Kunming is the capital, with Southeast and South Asian countries.

\section{K5: "If you want to get this information, you can only get through the English channels"}

$\mathrm{K} 5$ is a male cyber security engineer in his early thirties. He majored in cyber security at a top university in Shanghai. When he graduated, he worked in a leading company in Shanghai for three years. Then he came to Kunming and now works in a telecommunications company. K5 finds English indispensable for his work. $\mathrm{He}$ explained:

My work has so much to do with the security vulnerabilities among which many are discovered by the engineers abroad. Consequently, the exact technical details about the security vulnerabilities are definitely written in English. English acts as a tool in my work, which assists me to read the technical details and understand them. ... If I have some questions about the security vulnerability and the details, I might directly leave a message under the source article, or send an email to the writer.

As a cyber security engineer, K5 fixes security vulnerabilities as part of his regular work. A precondition for such work is understanding myriad technical details. Since most security vulnerabilities are discovered by engineers overseas, K5 uses English to stay in contact with counterparts overseas among his work-related community of practice. In addition, K5 puts the field of cyber security in China into a bigger picture, and sees a local and global nexus among relevant communities of practice. In this sense, English has a nexus function in connecting developing and developed regions and countries in the field of cyber security. The nexus function in relation to the use of English in this context can be understood as a bridging function that connects Chinese-English professionals with their international peers or counterparts, with English as a professional means for communication. K5 elaborated on this point:

I think that English is very important in my work. To be honest, compared with other regions and countries like America, China may not be as advanced in the field of cyber security, or even left far behind. Moreover, cyber security pays special attention to timing. That is to say, the timing of discovering a security vulnerability, one hour earlier or later, may lead to totally different consequences. For such a field where timing is of great importance, we need to catch up with the channels of information flow and exchange, and if we want to get this information, it seems that we can only get it directly through English channels. All in all, English plays a vital role in my work.

The above semi-structured interview data analysis of B1-B5 and K1-K5 shows that English has developed multiple functions in a range of domains in Chinese cities from business to the legal industry and state media, and from public and private education, clinical medicine, to cyber security engineering and the customs office of national boarder security. Both Beijing and Kunming are capital 
cities at the national and provincial levels of China, and the data analysis so far has shown that English has been extensively capitalized across domains of the cities involved in varying forms of capital, e.g., economic, social, and cultural. Both cities are multiethnic and multicultural, and they are open to the rest of the nation and the world now that Kunming is more explicitly connected to Southern and Central China and overseas towards ASEAN, while Beijing is more connected to Northern and Eastern China, as well as the rest of the world economically, culturally, and virtually via transmedia.

From a functional perspective, the tale of two cities is about the legitimacy of creativity and the adaptability of functionality by Chinese-English bilingual professionals for local and global communication. Viewing Chinese-English bilingual professionals and their English practices against the backdrop of the ongoing shifts and turns in World Englishes, and taking the Kachruvian functional perspective as an analytical framework, we see a wide range of functions that English fulfils in China.

Indeed, the data analysis shows the expanding functionality of English in China in two broader aspects, i.e., the "practical use" of English in Chinese contexts and the "essence" as an integral part of the developing identities of Chinese-English bilingual professionals. This expanding functionality ranges from instrumental, interpersonal, imaginative/innovative and regulative functions, as elaborated by B. Kachru (1992: 58), to ideational, personal, interactional, textual, representational/informative, and heuristic functions (Halliday 1973).

All ten participants in this investigation use English as a working language to varying degrees in their respective domains or professions. This reflects the instrumental function of English in China. The interpersonal and interactional functions are reflected among all the participants, as they build up and sustain workrelated relationships partly through English with colleagues, clients and students, as well as family members and friends for non-work-related interactions. The regulative function is reflected in the workplaces of $\mathrm{B} 3$ and $\mathrm{K} 4$, where the state media and border security serve as contexts for regulative channels for domestic and international audiences and travellers. The imaginative/innovative and personal functions are more saliently reflected in B1 and $\mathrm{K} 3$ who write prose and poetry in their spare time as a way to communicate creatively with their potential readers. The representational and informative functions for expressing proposition and relaying information are reflected in $\mathrm{B} 3, \mathrm{~K} 4$ and $\mathrm{K} 5$, as shown in the data analysis in this section. The heuristic function for exploring and discovering one's environment is evident in B1, B3, and K4, for example, B1's jobs require her to manage events and multilingual teams in different contexts and locations; B3 as a journalist would travel both domestically and internationally as part of his work routines to report news events and feature stories; and $\mathrm{K} 4$ as a customs officer works at an international airport, and all of these contexts and locations are environments that require the participants to explore and discover. 
In addition, the data analysis has shown the ever-expanding functionality of English in China, including English serving as a gateway to employment, e.g., B1, B2, and K2; a passport for high-end friendship ties and membership clubs, e.g., B1; a game-changer in terms of changing personal and professional life trajectories, e.g., B2. In terms of the paradigm shifts and turns surrounding World Englishes, Expanding Circle countries, such as China and Russia, do not only reflect those shifts and turns, but also enact and contribute to them. Proshina (2016: 205) points out that "in the Expanding Circle, the major function of English is providing intercultural communication. However, it is not the only function," as for Russia, "the turn of the century has seen a rapid increase in the range and functions of English." This is also the case for China, as evidenced in the "tale of two cities." English in China plays an overarching nexus function to connect local and global communities of practice, both explicitly in terms of the tangible functions or "practical use" (i.e., yong) of English, and implicitly in relation to the "essence" (i.e., ti) or the "invisible" function, in Y. Kachru and Nelson's (2006: 169) terms, "a gatekeeper and indicator of social status." It is evident that Chinese-English bilingual professionals indeed regard English as an integral part of their Chinese culture and self-identities, with feelings, emotions and subconsciousness as a way of getting connected to the outside world, and ultimately as a means of multilingual self-expression.

\section{Conclusion}

In this paper, we have explored the expanding functionality of English in two major Chinese cities, Beijing and Kunming. We have taken the major paradigm shifts and turns surrounding World Englishes as a backdrop to unpack the multiple functions of English for Chinese-English bilingual professionals in their various contexts and how their life and professional trajectories have been impacted by the paradigm shifts and turns. In particular, we have discovered that the multiple functions of English for Chinese-English bilingual professionals develop and evolve in two complementary directions, i.e., "practical use" or yong and the Chinese "essence" or $t i$. It is worth pointing out, based on the "tale of two cities," that English in China, together with Chinese in the verbal repertoires of ChineseEnglish bilingual speakers, serves an overarching nexus function in the sense that it connects the local with the global, the real and virtual realities, as well as multiple ethnicities and communities for a whole range of functions. It is hoped that through this "tale of two cities," we see further developments of functional world Englishes across the Kachruvian Circles. 


\section{Acknowledgements}

We would like to thank the editors of this issue, Prof. Zoya Proshina and Prof. Cecil Nelson, for their kind invitation, and the anonymous reviewers for their constructive comments, and our participants from the two cities of Beijing and Kunming for their openness and insightful conversations throughout the interviews.

(C) Xu Zhichang and Zhang Danya, 2020
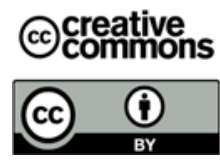

This work is licensed under a Creative Commons Attribution 4.0 International License https://creativecommons.org/licenses/by/4.0/

\section{REFERENCES}

Bachmann-Medick, Doris. 2009. Introduction: The translational turn. Translation Studies 2 (1). $2-16$.

Baker, Colin. 2011. Foundations of Bilingual Education and Bilingualism. $5^{\text {th }}$ edn. Bristol: Multilingual Matters.

Bernstein, Basil. 1966. Elaborated and restricted codes: An outline. Sociological Inquiry 36 (2). 254-261.

Canagarajah, Suresh. A. 2017. The nexus of migration and language: The emergence of a disciplinary space. In Suresh A. Canagarajah (ed.), The Routledge Handbook of Migration and Language, 1-28. London \& New York: Routledge.

Clyne, Michael. 2003. Towards a more language-centred approach to plurilingualism. In JeanMarc Dewaele, Alex Housen \& Wei Li (eds.), Bilingualism: Beyond Basic Principles, 43 55. Clevedon: Multilingual Matters.

Dai, Fan \& Zheng, Wei. 2019. Self-translation and English-language creative writing in China. World Englishes 38 (4). 659-670.

Fang, Fan (Gabriel). 2018. Review of English as a medium of instruction in Chinese universities today: Current trends and future directions. English Today 34 (1). 32-37.

Halliday, Michael A. K. 1973. Explorations in the Functions of Language. London: Edward Arnold.

Hlavac, Jim \& Zhichang Xu. 2020. Chinese-English Interpreting and Intercultural Commmunication. London and New York: Routledge.

Kachru, Braj B. 1983. The Indianization of English: The English Language in India. New Delhi: Oxford University Press.

Kachru, Braj B. 1985. The bilinguals' creativity. Annual Review of Applied Linguistics 6. $20-33$.

Kachru, Braj B. 1992. Models for Non-Native Englishes. In Braj B. Kachru (eds.), The Other Tongue: English across Cultures. $2^{\text {nd }}$ edn, 48-74. Urbana \& Chicago: University of Illinois Press.

Kachru, Braj B. \& Cecil L. Nelson. 1996. World Englishes. In Sandra L. McKay \& Nancy H. Hornberger (eds.), Sociolinguistics and language teaching, 71-102. Cambridge: Cambridge University Press.

Kachru, Braj B. \& Larry Smith. 1985. Editorial. World Englishes 4 (2). 209-212.

Kachru, Yamuna \& Cecil L. Nelson. 2006. World Englishes in Asian Contexts. Hong Kong: Hong Kong University Press. 
Kirkpatrick, Andy. 2017. Future directions for researching Chinese English. In Zhichang Xu, Deyuan He \& David Deterding (eds.), Researching Chinese English: The State of the Art, 267-279. Cham, Switzerland: Springer.

Kirkpatrick, Andy, \& Zhichang Xu. 2002. Chinese pragmatic norms and 'China English.' World Englishes 21 (2). 269-279.

Kuhn, Thomas S. 1996. The Structure of Scientific Revolutions. $3^{\text {rd }}$ edn. Chicago, IL: University of Chicago Press.

Li, Wei. 2011. Moment analysis and translanguaging space: Discursive construction of identities by multilingual Chinese youth in Britain. Journal of Pragmatics 43 (5), 12221235 .

Li, Wei. 2018. Translanguaging as a practical theory of language. Applied Linguistics 39 (1). 9-30.

Ma, Qing \& Zhichang Xu. 2017. The nativization of English in China. In Zhichang Xu, Deyuan He \& David Deterding (eds.), Researching Chinese English: The State of the Art, 189201. Cham, Switzerland: Springer.

May, Stephen. 2014. Disciplinary divides, knowledge construction, and the multilingual turn. In Stephen May (ed.), The Multilingual Turn: Implications for SLA, TESOL, and Bilingual Education, 7-31. New York \& London: Routledge.

Pennycook, Alastair. 2010. Rethinking origins and localization in Global Englishes. In Mukul Saxena \& Tope Omoniyi (eds.), Contending with Globalization in World Englishes, 196-210. Bristol: Multilingual Matters.

Proshina, Zoya G. 2014. Language revolution behind the cultural curtain. World Englishes 33 (1). $1-8$.

Proshina, Zoya G. 2016. Legitimacy of Russian English. Procedia: Social and Behavioral Sciences 236. 201-206.

Proshina, Zoya G. \& Irina Ustinova. 2012. English and Asian Flavor in Russian Advertising of the Far East. Asian Englishes 15 (2). 30-59.

Seargeant, Philip. 2010. Naming and defining in world Englishes. World Englishes 29 (1). 97-113.

Seargeant, Philip \& Caroline Tagg. 2011. English on the internet and a 'post-varieties' approach to language. World Englishes 30 (4). 496-514.

Sridhar, S. N. \& Kamal K. Sridhar. 2018. Coda 2. A bridge half-built: Toward a holistic theory of Second Language Acquisition and world Englishes. World Englishes 37 (1). 127-139.

Sui, Gang. 2015. Bilingual creativity: University-level poetry writing workshops in English in China: How is 'contact literature' created? English Today 31 (3). 40-45.

$\mathrm{Xu}$, Zhichang. 2009. Linguistic, cultural and identity issues in Englishization of Putonghua. In Kwok-kan Tam (ed.), Englishization in Asia: Language and Cultural Issues, 119-139. Hong Kong: Open University of Hong Kong Press.

$\mathrm{Xu}$, Zhichang. 2010. Chinese English: Features and Implications. Hong Kong: Open University of Hong Kong Press.

$\mathrm{Xu}$, Zhichang. 2017. Developing meta-cultural competence in teaching English as an International Language. In Farzad Sharifian (ed.), Advances in Cultural Linguistics, 703-720. Cham: Switzerland: Springer.

Xu, Zhichang. 2020. Exploring Functional Variations of Cultural Semiotics in Ha Jin's Facing Shadows. In Ram Ashish Giri, Anamika Sharma \& James D'Angelo (eds.), Functional Variations in English: Theoretical Considerations and Pactical Challenges, 78-89. Cham, Switzerland: Springer. 
Article history:

Received: 30 April 2020

Revised: 13 July 2020

Accepted: 15 July 2020

\section{История статьи:}

Дата поступления в редакцию: 30 апреля 2020

Дата принятия к печати: 15 июля 2020

\section{Bionotes:}

Zhichang $\mathrm{XU}, \mathrm{PhD}$, is a senior lecturer in the School of Languages, Literatures, Cultures and Linguistics at Monash University, and associate editor for English Today (Cambridge University Press). He has a disciplinary background in applied linguistics and intercultural education. His research areas include world Englishes, applied linguistics, cultural linguistics, intercultural communication, and language education. He has published a research monograph and an edited volume on Chinese English, as well as book chapters, and journal articles in journals such as World Englishes, International Journal of English as a Lingua Franca, Journal of Asian Pacific Communication, Asian Englishes, Intercultural Pragmatics, and Multilingual Education.

\section{Contact information:}

School of Languages, Literatures, Cultures and Linguistics, Faculty of Arts. Monash University. E577, 20 Chancellors Walk, Clayton Campus, Wellington Road, Clayton VIC 3800, Melbourne, Australia

e-mail: zhichang.xu@monash.edu

ORCID ID: 0000-0002-9789-3225

Danya ZHANG is a lecturer in the School of Foreign Languages and Literature at Yunnan Normal University, China. She is a PhD candidate in Linguistics and Applied Linguistics at Monash University, Australia. Her research interests include world Englishes and applied linguistics.

\section{Contact information:}

School of Foreign Languages and Literature, Yunnan Normal University.

Mingde Building, Chenggong Campus; Yuhua Pianqu, Chenggong District, 650500, Kunming, Yunnan Province, China e-mail: danya.zhang1@monash.edu

ORCID ID: 0000-0003-0169-5628

\section{Сведения об авторах:}

Чжичан СЮЙ, $\mathrm{PhD}$, преподает в Школе языков, литератур, культур и лингвистики Университета Монаша. Является ассоциативным редактором журнала English Today (Изд-во Кембриджского университета). Занимался прикладной лингвистикой и межкультурным образованием. Сейчас научные интересы сосредоточены на проблемах контактной вариантологии, методики преподавания языков, культурной лингвистики, межкультурной коммуникации и языкового образования. Среди его трудов монография, ряд отдельных глав в коллективных монографиях и статей в таких журналах, как World Englishes, International Journal of English as a Lingua Franca, Journal 
of Asian Pacific Communication, Asian Englishes, Intercultural Pragmatics, Multilingual Education.

Контактная информация:

School of Languages, Literatures, Cultures and Linguistics, Faculty of Arts, Monash University. E577, 20 Chancellors Walk, Clayton Campus, Wellington Road, Clayton VIC 3800, Melbourne, Australia

e-mail: zhichang.xu@monash.edu

ORCID ID: 0000-0002-9789-3225

Данья ЧЖАН преподает на факультете иностранных языков и литературы Юньнаньского педагогического университета, Китай. Обучается в аспирантуре Университета Монаша, Австралия, по направлению «Лингвистика и прикладная лингвистика». Ее научные интересы сосредоточены на контактной вариантологии английского языка и методике преподавания языка.

\section{Контактная информация:}

School of Foreign Languages and Literature, Yunnan Normal University.

Mingde Building, Chenggong Campus; Yuhua Pianqu, Chenggong District, 650500, Kunming, Yunnan Province, China

e-mail: danya.zhang1@monash.edu

ORCID ID: 0000-0003-0169-5628 